\title{
How the carotid body works: Different strategies and preparations to solve different problems
}

\author{
PATRICIO ZAPATA and CAROLINA LARRAÍN
}

Laboratorio de Neurobiología, Pontificia Universidad Católica de Chile, Santiago, Chile, and Facultad de Medicina, Clínica Alemana - Universidad del Desarrollo, Santiago, Chile

\begin{abstract}
This is a review of the different experimental approaches developed to solve the problems in our progress towards a comprehensive understanding of how arterial chemoreceptors operate. An analysis is performed of the bases, advantages and limits of the following preparations: studies of ventilatory reflexes originated from carotid bodies (CBs) in the entire animal; recordings of $\mathrm{CB}$ chemosensory discharges in situ; $\mathrm{CB}$ preparations perfused in situ; $\mathrm{CB}$ explants in oculo; $\mathrm{CB}$ explants in ovo; $\mathrm{CB}$ preparations incubated in vitro; CB preparations superfused in vitro; $\mathrm{CB}$ preparations perfused and superfused in vitro; $\mathrm{CB}$ tissue slices in vitro; cells acutely dissociated from CBs; CB cells in tissue culture; petrosal ganglia superfused in vitro; petrosal ganglion cells in tissue culture; and co-cultures of CB and sensory ganglion cells. A brief historical account is given of the passage from one preparation to the next one. Emphasis is placed on personal experience with the different preparations whenever possible. Examples are given of the importance of selecting the appropriate experimental preparation for solving each particular theoretical problem. In fact, brilliant ideas on how the CB works have been unproductive until finding the adequate experimental approach to explore the validity of such ideas.
\end{abstract}

Key terms: arterial chemoreceptors, carotid body, chemosensory activity, co-cultures, cultures, in situ, in vitro, petrosal ganglia, superfusion.

\section{INTRODUCTION}

Compared to other organs, the history of the carotid body (glomus caroticum) is rather brief and recent. The small size of this organ explains why it was referred to as ganglion minutium in the first anatomical report on its existence in the human body, Hartwig Taube's Doctoral Thesis in 1743, although its discovery was attributed to his mentor, Albrecht von Haller (see Pick, 1959). However, the histological studies performed by Fernando de Castro (1926, 1928) constituted the basis for its consideration as a sensory receptor for the chemical changes occurring in the blood.

The two main anatomical characteristics of the carotid body are its rich vascularization and its rich innervation. They have important consequences for the performance of physiological studies: the oxygen supply to the organ has to be well preserved and the functionality of the organ is commonly ascertained from electrical recordings of sensory nerve activity or the resultant chemoreflex changes in the animal's respiration.

\section{ELICITATION OF VENTILATORY CHEMOREFLEXES IN PREPARATIONS IN TOTO}

Despite the fact that the carotid bodies are the most relevant sites of origin of ventilatory chemoreflexes, the first report on reflex respiratory regulation was related to the aortic bodies (Heymans \& Heymans, 1927) and was based on observations performed on dogs with cross-circulation, using asphyxia (i.e., hypoxia, hypercapnia 
and acidemia) as the stimulus. Three years later, Heymans, Bouckaert \& Dautrebande (1930) reported that hypoxic, hypercapnic and acidotic stimulation of the carotid bifurcation region could induce reflex hyperventilation.

The study of ventilatory chemoreflexes is based on the direct relationship between arterial chemoreceptor activity (as input) and ventilatory volume (as output). But the transference of afferent into efferent activities depends on the gain of intervening central synapses, and it is there where anesthetic agents may interfere. Reflex ventilatory responses to hypoxia may be depressed by barbiturates (Hirshman et al., 1975), as well as by halothane, enflurane and isoflurane (Hirschman et al., 1977), while they may be enhanced by chloralose (Schmidt, 1938). This may be true, but for many years in our work on cats, we have used pentobarbitone (given intraperitoneally for induction and followed by iv supplementary doses), and this results in a very regular pattern of basal breathing and consistent (and repeatable) dose-response curves for reflex ventilatory stimulants (see, e.g., Eugenín et al., 1989, 1990), making this an excellent preparation for testing chemoreflex changes in ventilation caused by physiological, pharmacological or surgical (e.g., partial chemodeafferentation) conditions. On the other hand, apart from its potential toxicity, chloralose anesthetized preparations are indeed very reactive (even to room noises), but we have observed that resting ventilation is not very regular and reflex changes in response to chemostimulants are of variable amplitude (Serani et al., 1983), making it more difficult to establish statistically significant changes in ventilatory and cardiovascular parameters.

The contribution of carotid nerves to ventilatory chemoreflexes has been established by sectioning one or both of them, as well as by isolating the reflex influences of both intact carotid nerves after interruption of both aortic nerves (Eugenín et al., 1989). The advantage of this preparation is that ventilatory chemoreflexes may be tested for regulatory adjustments after chronic partial chemodeafferentation (Eugenín et al., 1990) or repeated hypoxic challenges (del Río et al., 2004; Iturriaga et al., 2005).

Due to the short neck of rats and mice and the small size of their carotid nerves, the exploration of carotid chemoreceptors in these species is commonly dependent on analyses of their ventilatory chemoreflexes (Cárdenas \& Zapata, 1981, 1983).

Furthermore, preparations in toto offer the only direct way to demonstrate the reflex influence exerted by the carotid bodies upon a given physiological phenomenon or a distant organ, by studying a related function in the presence and absence of carotid body afferences. Thus, the role of the arterial chemoreceptors in the control of the pattern and frequency of spontaneous gasps was established by recording such ventilatory variables first when the carotid nerves were still intact and then after their interruption (Zuazo \& Zapata, 1980).

What is the advantage nowadays of studying ventilatory chemoreflexes in preparations in toto? Or is it merely a primitive approach to study the function of the carotid body? The answer depends on the question for performing a given research. If the interest rests upon respiratory regulation and how it is affected by chemoafferent influences, this preparation still may provide valuable information and, in some cases, is the most suitable for reaching significant experimental results. On the other hand, upon observing a given response in a restricted preparation (e.g., glomus cells in culture, isolated sensory ganglion cells, nucleus tractus solitarius synapses), one is tempted to ask if such response introduces a statistically significant change (and how intense it is) into the entire performance of the ventilatory chemoreflex pathway. The preparation under consideration is the only one to provide such an answer.

As an example of the present usefulness of this preparation, let us mention a recent observation. Upon finding in petrosal ganglia superfused in vitro that sensory neurons projecting to the carotid body (and sinus) are selectively responsive to topical applications of acetylcholine and nicotine 
(Alcayaga et al., 1998), we asked ourselves whether such cholinoceptive sites in presumably chemosensory perikarya contribute somehow to the well-known ventilatory chemoreflex responses to cholinergic agonists. We confirmed that ventilatory chemoreflexes to intravenous injections of nicotine usually were eliminated by sectioning the carotid and aortic nerves -afferent pathways from carotid and aortic bodies, respectively- and, we also observed that the reflex hyperventilation elicited by intracarotid injections of nicotine -or its topical application to the carotid body surface- was suppressed by sectioning the ipsilateral carotid nerve (Fernández et al., 2002), a neurotomy that does not interrupt the afferent pathway between the petrosal ganglion and the ventilatory centers of the medulla oblongata. Thus, although the somata of petrosal ganglion neurons are endowed with nicotinic $\mathrm{ACh}$ receptors, they do not provide a reflex source for eliciting ventilatory changes.

A theoretical analysis of the "wholeanimal approach' appears in the present issue of this journal (Serani et al., 2005).

\section{RECORDING OF CAROTID NERVE CHEMOSENSORY} DISCHARGES IN SITU

The first recordings of the electrical activity of the carotid (sinus) nerve revealed the presence of the rhythmical barosensory discharges originated from the carotid sinus (Bronk \& Stella, 1932; Heymans \& Rijlant, 1933). Shortly, thereafter, the chemosensory discharges originated from the carotid body were recorded and the responses to asphyxia (Bogue \& Stella, 1935), acidosis (Zotterman, 1935), hypercapnia (Samaan \& Stella, 1935), hypoxia (von Euler et al., 1939) and acetylcholine (von Euler et al., 1941) were illustrated.

In fact, recordings of the electrical activity of the entire carotid nerve in situ are dominated by the pulse-related bursts of the usually larger action potentials of barosensory fibers. To obtain a clear picture of the random discharges of chemosensory fibers, the barosensory discharges are eliminated by interrupting nerve connections between the carotid body and sinus (Zotterman, 1935; Álvarez-Buylla, 1954; Zapata et al., 1969a), or by reducing arterial pressure below the firing threshold of carotid sinus baroreceptors (Zotterman, 1935; Zapata et al., 1969b).

Another way of recording carotid nerve chemosensory discharges in situ is by dissecting filaments of the nerve containing few or single fibers (e.g., Eyzaguirre \& Lewin, 1961a; McQueen, 1977). These single-unit recordings are suitable for detailed analyses of pulse intervals, such as histograms of distribution, but only very small samples of the total population of fibers could be investigated on each experiment (McQueen, 1983). On the other hand, multi-unit recordings from the entire carotid nerve present better stability than single fiber preparations, especially during prolonged recordings; and they minimize the problem of individual fiber variability, allowing for the opportunity to obtain statistically significant data from a small number of experiments (Fitzgerald \& Osborne, 1987). Comparison of responses of single and multiple units show them to be remarkably homogeneous (Goodman, 1974). Nevertheless, the analyses of both types of recordings rest on the sequential changes in the frequency of chemosensory discharges.

We have made use of carotid nerve recordings in situ to reveal chemosensory responses to stimuli supplied by inhalation or iv injections to the entire animal (e.g., nicotine administration in Zapata et al., 1976 a, b), close-arterial intracarotid injections (Reyes et al., 2005) and topical application to the carotid body surface (Fernández et al., 2002). On simultaneous recordings of the chemosensory activities of both carotid nerves, a high degree of coherence is found in their responses to systemic stimulant and depressant agents (Alcayaga et al., 1997), pointing to the idea that both carotid nerves convey similar (redundant) information to the brain stem. Furthermore, when sectioning one carotid nerve for recording and leaving intact the contralateral one, a high correlation is found between the changes in chemosensory activity of one carotid nerve 
(input) and the changes in phrenic nerve activity (output) reflexly mediated by the other carotid nerve (Iturriaga et al., 1994a).

Chemosensory discharges, originated from the carotid body, have been obtained in situ from extracellular recordings with tungsten microelectrodes of the connected petrosal ganglion (Vidruk \& Dempsey, 1980). This provides the opportunity for a detailed analysis of the discharges of single chemosensory units.

A peculiar preparation merits mentioning. Working in very difficult conditions, De Castro (1951) had to make use of crossanastomoses of nerves in cats to reveal the appearance of chemosensory activity in the decentralized peripheral vagus nerve (with perikarya in the nodose ganglion) sutured to the peripheral (degenerating) end of the glossopharyngeal nerve (from which the carotid nerve emerges). Unable to record the electrical activity of the reinnervating fibers, he also had sutured the supranodosal vagus to the cervical sympathetic trunk. After a prolonged period of time, he stimulated the carotid body with hypercapnic acidic solutions and observed pupillary dilation as response. Thus, De Castro had reinnervated the carotid body with vagal sensory fibers whose central processes had been regenerated to the superior cervical ganglion, establishing synapses with the postganglionic sympathetic neurons innervating the pupil. In fact, the pupil had replaced an oscilloscope. A full and illustrated account of this ingenious procedure was reported in this journal (Eyzaguirre \& Zapata, 1982).

\section{CAROTID BODY PREPARATIONS PERFUSED IN SITU}

Since vascular isolation of the carotid bifurcation in situ and its filling with saline solutions at controlled pressures has been a common technique for the study of barosensory discharges, several attempts have been made to perfuse the carotid body (in fact the carotid bifurcation) in situ with saline to study carotid nerve chemosensory discharges. Such preparation has been used for studying carotid nerve chemosensory responses to abrupt changes in $\mathrm{pH}$ and $\mathrm{pCO}_{2}$ (Gray, 1968) and to cholinergic and metabolic blockers (Joels \& Neil, 1968), but the viability of the preparation cannot be prolonged for more than $90 \mathrm{~min}$, because of edema formation, even when adding dextran to the perfusing solution.

Contrarily to the above, the carotid body preparations perfused in situ with blood may be maintained in better conditions. Thus, to study the effects of blood temperature upon chemoreceptor activity, the common carotid was cannulated both ways with a siliconized rubber coil, within which circulating blood could be modified by a heat-exchanger (McQueen \& Eyzaguirre, 1974).

It was found that the vascularly isolated carotid body perfused in situ with saline solutions underwent prompt and marked reductions in its chemosensitivity and $\mathrm{O}_{2}$ usage (O'Regan, 1979); and within $15 \mathrm{~min}$ of saline perfusion, glomus cells and sensory nerve endings showed swelling and disruption of cristae of their mitochondria (Cottell et al., 1984). Damage is postponed if the carotid body is maintained under circulation with blood and saline perfusions are restricted to very brief periods. This is why selective saline perfusion of the carotid bifurcation with a cocktail of cholinergic antagonists was restricted to two-minute periods of time when attempting to block chemosensory responses to hypoxia (Fitzgerald \& Shirahata, 1994).

\section{CAROTID BODY EXPLANTS IN OCULO}

Carotid bodies have been excised from rats and transplanted into the anterior chamber of the eye of the same animals (Kondo, 1978; Paivarinta \& Eränkö, 1984). Glomus and sustentacular cells were recognized in the transplants. They became vascularized and innervated by fibers originated from the host tissue.

\section{CAROTID BODY EXPLANTS IN OVO}

Carotid bodies also have been excised from rats and grafted onto the chorioallantois of chick embryos (Gual et al., 1991), which resulted in vigorous angiogenesis at the site of the transplant, supporting nests of glomus 
cells. The problem is that host cells initially favor the growth of the implant, but later invade it and disorganize foreign cells.

Rat nodose ganglia also have been grafted onto the chorioallantois of chick, thus allowing for co-transplants with carotid bodies (Eugenín \& Eyzaguirre, 2005).

\section{CAROTID BODY PREPARATIONS INCUBATED IN VITRO}

As mentioned in the second paragraph of this paper, the rich vascularization and $\mathrm{O}_{2}$ demands of the carotid body require its continuous perfusion and/or superfusion when it is excised and studied in in vitro conditions. Nevertheless, continuously perfused or superfused preparations are not adequate for administering radioactive substances to the tiny carotid body or measuring the release of radiolabeled substances from carotid body tissues. Many years ago, we (Donoso et al., 1970) had the opportunity to search for the incorporation of tritiated choline to cat carotid bodies incubated in vitro at $37^{\circ} \mathrm{C}$. To establish the viability of such preparations incubated in vials containing small volumes of saline $(<2$ $\mathrm{ml}$ ) not subjected to flow, we recorded the action potentials from single fibers or the entire carotid nerve lifted to an oil layer. High frequencies of carotid nerve discharges were recorded, as expected for preparations subjected to arrested flow (see later) of nonbubbled saline, but they persisted for 2-3 hours of incubation.

It must be noted that this type of preparation is commonly used during the initial period of incubation of carotid bodies exposed to radiolabeled precursors of suspected transmitters (e.g., Fidone et al., 1982), and it is still in use in carotid body preparations successively exposed to incubations with different concentrations of tested agents or $\mathrm{O}_{2} / \mathrm{N}_{2}$ mixtures (see Fitzgerald et al., 2004).

\section{CAROTID BODY PREPARATIONS SUPERFUSED IN VITRO}

To advance the understanding of arterial chemoreceptor physiology, the establishment of the precise relationships between variations in "natural" chemical stimuli $\left(\mathrm{P}_{\mathrm{a}} \mathrm{O}_{2}, \quad \mathrm{P}_{\mathrm{a}} \mathrm{CO}_{2}, \quad \mathrm{pH}_{\mathrm{a}}\right)$ and changes in chemosensory nerve activity was required. Nonetheless, it was not easy to obtain an intact carotid body preparation in situ in which changing one of these stimuli was almost immediately associated with changes in the others. As a result, it was not possible to establish whether the responses to physical stimulants (arterial pressure, blood flow, blood temperature, osmolarity, etc.) and pharmacological agents (ACh, nicotine, noradrenaline, dopamine, serotonin, etc.) resulted from direct effects on chemoreceptors themselves or were secondary effects to changes in blood flow through carotid body tissue. Contradictory reports were not uncommon, and they were attributed to uncontrolled variations.

To resolve the above problems, Prof. Carlos Eyzaguirre, in the Department of Physiology, University of Utah, worked hard to obtain an isolated preparation of the carotid body in vitro superfused with saline solutions flowing at a controlled rate, and in which one controlled change in chemical constituents or physical conditions would be introduced at a time without affecting other variables of the experiment. Physiological observations on such carotid body in vitro superfused preparations appeared (Eyzaguirre \& Lewin, 1961b; Eyzaguirre \& Koyano, 1965; Eyzaguirre \& Zapata, 1968). But it was difficult to even imagine how a tissue demanding a high $\mathrm{O}_{2}$ supply and provided with a high blood flow could survive in vitro. Such skepticism was expressed throughout a symposium on arterial chemoreceptors held in Oxford University (Torrance, ed., 1968), but experimental facts prevailed upon theoretical considerations. The oxygen consumption of the carotid body superfused in vitro was measured (Leitner \& Liaubet, 1971). Verna et al. (1981) observed that glomus cells and sensory nerve endings of carotid bodies superfused with saline for up to six hours retain their normal ultrastructural and histochemical features. Carotid body preparations superfused in vitro do indeed survive for many hours (1218 hours). In fact, in our experience, 
experiments are commonly ended not because of deterioration of the preparation, but because of the impending fatigue of the researchers!

The carotid body superfused in vitro revealed that this is indeed a "multimodal" receptor, responding directly to various chemical and physical changes that may occur under physiological conditions: oxygen and carbon dioxide tensions; hydrogenion, glucose and potassium concentrations; temperature, osmolarity and volume flow (see Zapata, 1997a). It also allowed the separation of the direct effects of pharmacological agents on the chemoreceptor apparatus itself from those mediated by vascular changes affecting the carotid body (see Zapata, 1997b).

This preparation also has been used to correlate changes in the electrophysiological activity continuously recorded from the carotid nerve with changes in dopamine release from the carotid bodies _ previously incubated with radiolabeled tyrosine _ when superfused with saline equilibrated at different $\mathrm{O}_{2}$ tensions (Fidone et al., 1982) or exposed to acidified media (Rigual et al., 1984). More recently, we obtained a fast temporal resolution of dopamine release by using high-speed chronoamperometry and correlated it with changes in carotid nerve activity elicited by brief hypoxic challenges (Iturriaga et al., 1996). Both studies reveal dopamine release from the glomus cells of carotid bodies exposed to hypoxia, but the latter indicates that such release cannot serve as the transmitter for the excitation of carotid nerve chemosensory nerve endings.

The carotid body preparation superfused in vitro also has been used to compare changes in ATP level in the carotid body with the electrical activity of the carotid nerve (Obeso et al., 1985): hypoxia, cyanide, and 2-deoxy-glucose, all the three effective as stimulants for chemosensory activity and releasers of dopamine from carotid body tissues, caused reduction of ATP levels in the superfused carotid bodies.

A superfused preparation of the carotid body connected to the petrosal ganglion has been obtained from mice (Donnelly \& Rigual, 2000). This preparation allowed the recording of spontaneous and evoked activities from single chemosensory units from the petrosal ganglion through a suction electrode.

\section{CAROTID BODY PREPARATIONS PERFUSED/ SUPERFUSED IN VITRO}

Belmonte and Eyzaguirre introduced this type of preparation, in 1974, working at the Department of Physiology, University of Utah. After heparinization, the common and external carotids were cannulated, and the entire carotid bifurcation, with the carotid nerve, was placed within a superfusion chamber; the preparation was thus perfused intravascularly with dextran-containing saline through the cannulas and superfused externally with saline. This set-up was used to study the effects of efferent stimulation on carotid chemosensory activity, allowing the discrimination between direct and vascularly mediated effects (Belmonte \& Eyzaguirre, 1974).

This preparation was reintroduced later by a group of researchers working at the Department of Physiology, University of Pennsylvania (Iturriaga et al., 1991). Its advantage is the brief latency and short duration of chemosensory responses, with respect to those observed in simply superfused preparations. However, the viability of the preparation is shorter than that which only has been superfused.

\section{COMPARISON BETWEEN CAROTID BODY}

PREPARATIONS IN SITU AND IN VITRO

Some comments on the comparative advantages and disadvantages of preparations superfused in vitro are worth mentioning.

Considering the high blood flow through the carotid body, the question arises whether chemosensory activity is affected directly by flow through this organ. Unilateral common carotid artery occlusions silence the barosensory impulses recorded from the ipsilateral carotid nerve and, at the same time, may increase the rate of its chemosensory discharges (Alcayaga et al., 1986). When the carotid nerve was 
intact, barosensory withdrawal during carotid occlusion is mostly responsible for reflex hypertension and tachycardia, while chemosensory excitation induced by this maneuver is the major cause of reflex hyperventilation (Iturriaga et al., 1988). Later studies on cat carotid bodies in vitro superfused with saline flowing at various steady rates revealed that the mean frequency of chemosensory discharges is inversely dependent on the rate of flow, with saline equilibrated with either $20 \% \mathrm{O}_{2}$ or $100 \% \mathrm{O}_{2}$ (Alcayaga et al., 1988). Thus, studies in vitro concluded that the carotid body may serve as a "rheoreceptor."

Increasing the temperature of blood perfusing the vascularly isolated carotid bodies of dogs leads to reflex increases in breathing (Bernthal \& Weeks, 1939). Studies on cat carotid bodies in situ showed that the discharge frequency of chemosensory fibers recorded from the carotid nerve increases when warming the blood circulating through the carotid bifurcation and decreases when cooling this blood (McQueen \& Eyzaguirre, 1974). Later studies were performed on carotid bodies in vitro. Recordings from single fibers of the carotid nerve showed extremely high temperature coefficients $\left(Q_{10}\right)$ and apparent activation energies $(\mu)$ for chemosensory frequencies (Gallego et al., 1979). Studies on preparations superfused with saline equilibrated with $100 \% \mathrm{O}_{2}$ revealed that thermal increases by $0.5^{\circ} \mathrm{C}$ steps between 36.0 and $38.5^{\circ} \mathrm{C}$ resulted in sustained increases in the frequency of carotid nerve chemosensory discharges (Alcayaga et al., 1993). Thus, studies on preparations in vitro concluded that the carotid body may serve as a "thermoreceptor" for blood circulating towards the head. Now, on returning to preparations in situ, it was found that raising body temperature from $35^{\circ}$ to $40^{\circ} \mathrm{C}$ progressively increased the frequency of chemosensory discharges, but the effect was blunted by the simultaneously increased alveolar ventilation (Loyola et al., 1991). Similarly, raising body temperature from $37^{\circ}$ to $40^{\circ} \mathrm{C}$ by external heat in pentobarbitone-anesthetized cats with intact carotid nerves increased respiratory frequency, tidal volume and frequency of spontaneous gasps, the last two effects being abolished by previous section of both carotid nerves (Fadic et al., 1991).

One of us (Zapata, 1975, 1977) had reported the inhibitory effect of dopamine upon chemosensory discharges originated from cat carotid bodies superfused in vitro, that is not explained by vascular effects (absent in this preparation), but desensitization was observed after several applications of this substance. Thus, the response was not reproducible in time, precluding its pharmacological characterization. Switching from in vitro experiments to in situ experiments was this time a successful strategy. Intravenous injections of dopamine inhibited chemosensory discharges originated from cat carotid bodies in situ, an effect highly reproducible even when injecting this drug at short intervals and over many hours (Llados \& Zapata, 1978a), allowing the full characterization of receptors involved in this reaction (Llados \& Zapata, 1978b; Zapata \& Larraín, 1978; Zapata \& Torrealba, 1984). The reverse strategy went further towards characterizing the reflex ventilatory effects evoked by dopamineinduced chemosensory inhibition of the carotid bodies and their reversal by dopamine antagonists (Zapata \& Zuazo, 1980, 1982; Iturriaga et al., 1994b).

\section{CAROTID BODY TISSUE SLICES IN VITRO}

This preparation is obtained by cutting the carotid body into thin slices, which are placed on the stage of an inverted microscope, bathed in flowing saline and observed with Nomarski optics during impalement with microelectrodes. It was also developed at the Department of Physiology, University of Utah (Fidone et al., 1971). The first report regarding its use on carotid body tissues dates to 1982 (Eyzaguirre \& Monti-Bloch, 1982).

This preparation has allowed researchers to impale -under direct visualizationglomus cells (Eyzaguirre et al., 1989) and sensory nerve endings (Hayashida et al., 1980) and thus obtain intracellular 
recordings from them. This preparation has been extremely useful to study electrotonic coupling between glomus cells, as well as more recently between glomus cells and chemosensory nerve endings (Eyzaguirre, 2005).

Using essentially a similar preparation, patch-clamp recordings have been obtained from glomus cells, using either the wholecell or the excised patch configurations (López-Barneo \& Pardal, 2003). The majority of these cells had voltagedependent currents qualitatively similar to those described in enzymatically dispersed glomus cells (Pardal \& López-Barneo, 2002). Hypoxia-induced catecholamine secretion has been detected from single glomus cells in thin slices of whole carotid bodies (Pardal et al., 2000).

\section{CELLS ACUTELY DISSOCIATED FROM CAROTID BODIES}

The patch-clamp technique has been applied extensively to glomus cells freshly dissociated from embryonic, neonatal and adult carotid bodies to study changes in membrane potential and ionic conductances in response to physiological stimuli (LópezBarneo et al., 1988; Biscoe \& Duchen, 1989; Peers, 1990; Donnelly, 1993; Buckler \& Vaughan-Jones, 1994; López-López et al., 1997).

This preparation also has allowed the use of fluorophores to study changes in intracellular $\mathrm{Ca}^{2+}$ concentration (Biscoe et al., 1989; Buckler \& Vaughan-Jones, 1994) and in intracellular $\mathrm{pH}$ (Buckler et al., 1991) of glomus cells in response to hypoxic and cytotoxic hypoxia, and external acidosis. Interestingly, acetylcholine - a putative transmitter released from glomus cells transiently increases the intracellular calcium concentration (Jiang \& Eyzaguirre, 2004).

\section{CAROTID BODY CELLS IN TISSUE CULTURE}

Significant progress has been made by research on tissue cultures obtained from dissociated carotid bodies. To our knowledge, the first report on a primary culture of cells from the carotid body was done by Pietruschka (1974).

Glomus cells (identified by tyrosine hydroxylase immunoreactivity) grow in monolayer clusters enveloped by sustentacular cells (identified by glial fibrillary acid protein immunoreactivity). Survival of glomus cells depends on oxygen tension and some growth factors. They retain the expression of both catecholaminergic (tyrosine hydroxylase, dopamine transporter) and cholinergic markers (choline acetyl transferase, vesicular acetylcholine transporter), as well as of $\mathrm{O}_{2}$-sensitive $\mathrm{K}^{+}$ channels (see Nurse \& Fearon, 2002).

Changes in membrane potential and intracellular $\mathrm{pH}$ have been recorded from cultured glomus cells (He et al., 1991), while decreases in $\mathrm{Na}^{+}$and $\mathrm{K}^{+}$currents are produced by extracellular or intracellular acidification (Stea et al., 1991). Cultured glomus cells from cats and pigs carotid bodies release acetylcholine when exposed to normoxic and hypoxic media (Shirahata et al., 1996), while acetylcholine itself increases intracellular $\mathrm{Ca}^{2+}$ of glomus cells (Shirahata et al., 1997). These observations point out that feedback phenomena may occur even at the cellular level and thus introduce variability to the entire chemoreceptor process.

\section{PETROSAL GANGLIA SUPERFUSED IN VITRO}

Since most afferent neurons innervating the carotid body and sinus in cats have their perikarya located within the petrosal ganglion - although only ca. $7 \%$ of its neurons provide the chemosensory innervation of the carotid body (see Eyzaguirre \& Zapata, 1984) - a preparation of the petrosal ganglion superfused in vitro to explore the characteristics of chemosensory neurons themselves was developed by Alcayaga et al. (1998). Since the petrosal ganglion was still attached to its peripheral branches, the carotid nerve and the main glossopharyngeal branch, separate recordings were made of the antidromic activity elicited in those branches by applying different drugs to the 
petrosal ganglion surface. The viability of the preparation was assessed by recording the compound action potentials of both branches evoked by electrical stimuli applied to the ganglion. The same procedure revealed whether upon reaching given concentrations, substances applied provoked local anesthetic blockade, which always must be distinguished from genuine receptor block.

Use of this preparation revealed that the perikaryal membrane of chemosensory neurons shares with the peripheral terminals membrane several common characteristics, among them the presence of wellcharacterized receptors for ACh, dopamine and ATP (Alcayaga et al., 1998, 1999a, 2000), while hypoxic sensitivity was absent from the perikaryon (Alcayaga et al., $1999 b)$, confirming the idea analyzed elsewhere that glomus cells attachment to peripheral chemosensory nerve endings is an essential requirement for oxygen sensing (Zapata, 2003).

Intracellular recordings from acutely excised petrosal ganglia previously had revealed that chemosensory neurons with myelinated axons exhibit a hump on the falling phase of the action potential, followed by prolonged after-hyperpolarization, while barosensory neurons of higher conduction velocity myelinated axons had action potentials without hump and followed by short after-hyperpolarization (Belmonte \& Gallego, 1983). Thus, the electrical properties of the perikarya of petrosal ganglia are different depending on their sensory modalities and target organs.

\section{PETROSAL GANGLION CELLS IN TISSUE CULTURE}

Petrosal ganglia removed from adult cats have been desheathed, pooled, minced, enzymatically dissociated, incubated, centrifuged, resuspended, seeded in Petri dishes and cultured. After 6-12 days, intracellular recordings had been obtained from ganglion cells. Their electrical properties did not differ essentially from those recorded from acutely dissociated cells (Alcayaga \& Arroyo, 1996). On recording whole cell currents (Stea \&
Nurse, 1992), two subpopulations of petrosal neurons had been found, differing in their sensitivity to blockade by tetrodotoxin, i.e., the contribution of voltage-dependent $\mathrm{Na}^{+}$channels to action potentials.

On whole-cell, patch-clamp recordings, acetylcholine sensitivity was observed in nearly two-thirds of petrosal neurons cultured from four hours to 14 days (Zhong \& Nurse, 1997). Acetylcholine induced a hexamethonium-sensitive inward current, mimicked by nicotine application. These findings indicate that a major subpopulation of petrosal sensory neurons express nicotinic acetylcholine receptors (nAChR), which are being characterized by testing a series of nicotinic agonists (Valdés et al., 2004).

Upon acute dissociation and culture for 7-12 days, sensory ganglion neurons showed action potentials with or without hump on their repolarizing phases, and prolonged or brief after-hyperpolarizations (Varas et al., 2000), as previously reported for acutely dissociated neurons (see above in ref. to Belmonte \& Gallego, 1983). Nearly two-thirds of both types of cultured neurons were sensitive to topically applied acetylcholine.

Tissue culture of sensory neurons from petrosal ganglia also has demonstrated catecholamine release from a population of these neurons on exposure to nicotine and high $\mathrm{K}^{+}$concentration (Iturriaga et al., 2003); probably the same population that had been found to be immunoreactive for tyrosine hydroxylase, the limiting enzyme for catecholamine synthesis (Katz et al., 1987).

\section{CO-CULTURES OF CAROTID BODY AND SENSORY GANGLION CELLS}

Co-cultures of glomus cells and sensory ganglion neurons recently have provided important hints with regard to the establishment of chemosensitivity (see Zhong \& Nurse, 1996).

Co-cultures of carotid body and nodose ganglion neurons allowed researchers to observe the ultrastructural and 
electrophysiological reconstitution of glomus cells to sensory neurons synapses (Alcayaga \& Eyzaguirre, 1990).

While petrosal ganglion neurons cultured alone are not responsive or are blocked by local acidification, neurons cocultured with carotid body cells exhibit a new $10 \%$ subpopulation that is depolarized, triggering trains of action potentials (Alcayaga \& Arroyo, 1996). Thus, only when attached to glomus cells, petrosal ganglion neurons become acidsensitive.

While petrosal ganglion neurons cultured alone are almost always quiescent and unresponsive to hypoxia, many of those co-cultured with carotid body cells display spontaneous spikes and subthreshold activity, the frequency of action potentials becoming higher upon exposure to hypoxia (Zhong et al., 1997). Thus, petrosal neurons only become electrically active when contacting with glomus cells, suggesting that glomus cells are the transducing elements for hypoxic stimulation, and they, in turn, activate sensory neurons. The possibility that transference of information between these cell types is mediated by chemical transmitters is indicated by the reversible suppression of the electrical activity of petrosal neurons exposed to a low $\mathrm{Ca}^{++}$-high $\mathrm{Mg}^{++}$external medium (Zhong et al., 1997).

\section{EPILEGOMENA}

Research on the carotid body physiology is a nearly 80-year-old enterprise. All along, it had depended on disposing adequate preparations to test the current hypotheses. An attractive title for this exploit should be: "from the entire organism to single channels." This is indeed the chronology of the availability of different preparations and techniques in the search for understanding arterial chemoreception. However, this should not be considered as a replacement of old procedures by new ones, but a progressive enrichment of available experimental strategies and techniques. Indeed, many of the advancements have resulted from the ingenuity to visualize how to solve a problem. The use of the classical preparations (e.g., assessing chemosensory activity from ventilatory chemoreflexes, chemosensory recordings from carotid bodies in situ) is well alive, as judged by the number of recent papers using such experimental approaches. And many times, exciting data provided by ex vivo procedures require the validation of their physiological meaningfulness by testing hypotheses in preparations in situ or in the entire animal.

\section{ACKNOWLEDGEMENTS}

This paper is written in gratitude for the Feitschrift in honor of PZ, held in December 2004, with the participation of many of his former associates, and organized by Drs Jaime Eugenín and Rommy von Bernhardi.

Most of the work of the authors reported here was performed at the Laboratory of Neurobiology, Pontificia Universidad Católica de Chile, Santiago, Chile. The initiation in carotid body research, under the direction of Professor Carlos Eyzaguirre to whom we are deeply indebted, was carried out at the Department of Physiology, University of Utah Medical School, Salt Lake City, Utah, USA.

This work was made possible by grants from the Gildemeister Foundation, the National (Chilean) Fund for Scientific \& Technological Development (FONDECYT), and the Research Division of the Pontificia Universidad Católica de Chile.

\section{REFERENCES}

ALCAYAGA J, ARROYO J (1996) Responses of cat petrosal ganglion neurons are modified by the presence of carotid body cells in tissue cultures. Adv Exp Med Biol 410: 195-201

ALCAYAGA J, EYZAGUIRRE C (1990) Electrophysiological evidence for the reconstitution of chemosensory units in co-cultures of carotid body and nodose ganglion neurons. Brain Res 534: 324-328

ALCAYAGA J, ITURRIAGA R, ZAPATA P (1986) Carotid body chemoreceptor excitation produced by carotid occlusion. Acta Physiol Pharmacol Latinoam 36: 199-215

ALCAYAGA J, ITURRIAGA R, ZAPATA P (1988) Flow dependent chemosensory activity in the carotid body superfused in vitro. Brain Res 455: 31-37 
ALCAYAGA J, SANHUEZA Y, ZAPATA P (1993) Thermal dependence of chemosensory activity in the carotid body superfused in vitro. Brain Res 600: 103111

ALCAYAGA J, ITURRIAGA R, ZAPATA P (1997) Time structure, temporal correlation and coherence of chemosensory impulses propagated through both carotid nerves in cats. Biol Res 30: 125-133

ALCAYAGA J, ITURRIAGA R, VARAS R, ARROYO J, ZAPATA P (1998) Selective activation of carotid nerve fibres by acetylcholine applied to the cat petrosal ganglion in vitro. Brain Res 786: 47-54

ALCAYAGA J, VARAS R, ARROYO J, ITURRIAGA R, ZAPATA P (1999a) Dopamine modulates carotid nerve responses induced by acetylcholine on the cat petrosal ganglion in vitro. Brain Res 831: 97-103

ALCAYAGA J, VARAS R, ARROYO J, ITURRIAGA R, ZAPATA P (1999b) Responses to hypoxia of petrosal ganglia in vitro. Brain Res 845: 28-34

ALCAYAGA J, CERPA V, RETAMAL M, ARROYO J, ITURRIAGA R, ZAPATA P (2000) Adenosine triphosphate-induced peripheral nerve discharges generated from the cat petrosal ganglion in vitro. Neurosci Lett 282: 185-188

ÁLVAREZ-BUYLLA R (1954) Disociación de las actividades quimiorreceptoras y barorreceptoras en gatos. Arch Inst Cardiol Méx 24: 26-37

BELMONTE C, EYZAGUIRRE C (1974) Efferent influences on carotid body chemoreceptors. J Neurophysiol 37: 1131-1143

BELMONTE C, GALLEGO R (1983) Membrane properties of cat sensory neurones with chemoreceptor and baroreceptor endings. J Physiol, Lond 342: 603-614

BERNTHAL T, WEEKS WF (1939) Respiratory and vasomotor effects of variations in carotid body temperature. A study of the mechanism of chemoreceptor stimulation. Am J Physiol 127: 94-105

BISCOE TJ, DUCHEN RM (1989) Electrophysiological responses of dissociated type I cells of the rabbit carotid body to cyanide. J Physiol, Lond 413: 447-468

BISCOE TJ, DUCHEN RM, EISNER DA, O'NEILL SC, VALDEOLMILLOS M (1989) Measurements of intracellular $\mathrm{Ca}^{2+}$ in dissociated type I cells of the rabbit carotid body. J Physiol, Lond 416: 421-434

BOGUE JY, STELLA G (1935) Afferent impulses in the carotid sinus nerve (nerve of Hering) during asphyxia and anoxaemia. J Physiol, Lond 83: 459-465

BRONK DW, STELLA G (1932) Afferent impulses in the carotid sinus nerve. I. The relation of the discharge from single end organs to arterial blood pressure. J Cell Comp Physiol 1: 113-130

BUCKLER KJ, VAUGHAN-JONES RD (1994) Effects of hypoxia on membrane potential and intracellular calcium in rat neonatal carotid body type I cells. J Physiol, Lond 476: 423-428

BUCKLER KJ, VAUGHAN-JONES RD, PEERS C, NYE PCG (1991) Intracellular $\mathrm{pH}$ and its regulation in isolated carotid body cells of the neonatal rat. J Physiol, Lond 436: 107-129

CÁRDENAS H, ZAPATA P (1981) Dopamine-induced ventilatory depression in the rat, mediated by carotid nerve afferents. Neurosci Lett 24: 29-33

CÁRDENAS H, ZAPATA P (1983) Ventilatory reflexes originated from carotid and extra-carotid chemoreceptors in rats. Am J Physiol 244: R119-R125

COTTELL DC, KENNEDY M, O'REGAN RG (1984) Ultrastructure of the cat carotid body perfused with saline solution. J Phsyiol, Lond 355: 46P

DE CASTRO F (1926) Sur la structure et l'innervation de la glande intercarotidienne (glomus caroticum) de l'homme et des mammifères, et sur un nouveau système d'innervation autonome du nerf glossopharyngien. Études anatomiques et expérimentales. Trab Lab Invest Biol Univ Madrid 24: 365-432

DE CASTRO F (1928) Sur la structure et l'innervation du sinus carotidien de l'homme et des mammifères. Nouveaux faits sur l'innervation et la fonction du glomus carotidien. Études anatomiques et physiologiques. Trab Lab Invest Biol Univ Madrid 25: 331-380

DE CASTRO F (1951) Sur la structure de la synapse dans les chemocepteurs: Leur mécanisme d'excitation et rôle dans la circulation sanguine locale. Acta Physiol Scand 22: $14-43$

DEL RÍO R, REY S, ARIAS P, ALCAYAGA J, ITURRIAGA R (2004) Chronic intermittent hypoxia enhances chemosensory and ventilatory responses to acute hypoxia. Biol Res 37: R-90

DONNELLY DF (1993) Response to cyanide of two types of glomoid cells in mature rat carotid body. Brain Res 630: $157-168$

DONNELLY DF, RIGUAL R (2000) Single-unit recordings of arterial chemoreceptors from mouse petrosal ganglia in vitro. J Appl Physiol 88: 1489-1495

DONOSO A, ZAPATA P, ÁLVAREZ J (1970) Incorporation of tritiated choline by the carotid body incubated in vitro. Arch Biol Med Exp 7: 1-7

EUGENÍN J, EYZAGUIRRE C (2005) Electrophysiological properties of rat nodose ganglion neurons co-transplanted with carotid bodies into the chick chorioallantoic membrane. Biol Res 38: 329-334

EUGENÍN J, LARRAÍN C, ZAPATA P (1989) Correlative contribution of carotid and aortic afferences to the ventilatory chemosensory drive in steady-state normoxia and to the ventilatory chemoreflexes induced by transient hypoxia. Arch Biol Med Exp 22: 395-408

EUGENÍN J, LARRAÍN C, ZAPATA P (1990) Functional recovery of the ventilatory chemoreflexes after partial chronic denervation of the nucleus tractus solitarius. Brain Res 523: 263-272

EYZAGUIRRE C (2005) Chemical and electric transmission in the carotid body chemoreceptor complex. Biol Res 38: 341-345

EYZAGUIRRE C, KOYANO H (1965) Effects of hypoxia, hypercapnia, and $\mathrm{pH}$ on the chemoreceptor activity of the carotid body in vitro. J Physiol, Lond 178: 385-409

EYZAGUIRRE C, LEWIN J (1961a) Chemoreceptor activity of the carotid body of the cat. J Physiol, Lond 159: 222-237

EYZAGUIRRE C, LEWIN J (1961b) Effect of different oxygen tensions on the carotid body in vitro. J Physiol, Lond 159: 238-250

EYZAGUIRRE C, MONTI-BLOCH L (1982) Nicotinic and muscarinic reactive sites in mammalian glomus cells. Brain Res 252: 181-184

EYZAGUIRRE C, ZAPATA P (1968) Pharmacology of pH effects on carotid body chemoreceptors in vitro. J Physiol, Lond 195: 557-588

EYZAGUIRRE C, ZAPATA P (1982) Trophic interactions between sensory nerves and their pre-neural elements. Arch Biol Med Exp 15: 219-228

EYZAGUIRRE C, ZAPATA P (1984) Perspectives in carotid body research. J Appl Physiol 57: 931-957

EYZAGUIRRE C, MONTI-BLOCH L, BARON M, HAYASHIDA Y, WOODBURY JW (1989) Changes in glomus cell membrane properties in response to stimulants and depressants of carotid nerve discharge. Brain Res 477: 265-279 
FADIC R, LARRAÍN C, ZAPATA P (1991) Thermal effects on ventilation in cats. Participation of carotid body chemoreceptors. Respir Physiol 86: 51-63

FERNÁNDEZ R, LARRAÍN C, ZAPATA P (2002) Acute ventilatory and circulatory reactions evoked by nicotine: Are they excitatory or depressant? Respir Physiol Neurobiol 133: 173-182

FIDONE S, O'LEARY T, EYZAGUIRRE C (1971) A simple method for the preparation of and recording from thin slices of living tissue. Brain Res 30: 401-406

FIDONE S, GONZÁLEZ C, YOSHIZAKI K (1982) Effects of low oxygen on the release of dopamine from the rabbit carotid body in vitro. J Physiol, Lond 333: 93110

FITZGERALD RS, OSBORNE JL (1987) The chemoreception of hypoxia and hypercapnia: Further evidence for a dual sensing mechanism. In: RIBEIRO JA, PALLOT DJ (eds) Chemoreceptors in Respiratory Control. London: Croom Helm. pp: 228-236

FITZGERALD RS, SHIRAHATA M (1994) Acetylcholine and carotid body excitation during hypoxia in the cat. $\mathrm{J}$ Appl Physiol 76: 1566-1574

FITZGERALD RS, SHIRAHATA M, CHANG I, BALBIR A (2004) L-arginine's effect on the hypoxia-induced release of acetylcholine from the in vitro cat carotid body. Respir Physiol Neurobiol 147: 11-17

GALLEGO R, EYZAGUIRRE C, MONTI-BLOCH L (1979) Thermal and osmotic responses of arterial receptors. J Neurophysiol 42: 665-680

GOODMAN NW (1974) Some observations on the homogeneity of response of single chemoreceptor fibers. Respir Physiol 20: 271-281

GRAY BA (1968) Response of the perfused carotid body to changes in $\mathrm{pH}$ and $\mathrm{PCO}_{2}$. In: TORRANCE RW (ed) Arterial Chemoreceptors. Oxford: Blackwell. pp: $297-$ 299

GUAL A, EUGENÍN J, ALCAYAGA J, STENSAAS LJ, EYZAGUIRRE C (1991) The chick chorioallantoic membrane promotes survival of co-transplanted rat carotid bodies and nodose ganglia. Brain Res 556: 139144

HAYASHIDA Y, KOYANO H, EYZAGUIRRE C (1980) An intracellular study of chemosensory fibers and endings. J Neurophysiol 44: 1077-1088

HE S-F, WEI J-Y, EYZAGUIRRE C (1991) Effects of relative hypoxia and hypercapnia on intracellular $\mathrm{pH}$ and membrane potential of cultured carotid body cells. Brain Res 556: 333-338

HEYMANS JF, HEYMANS C (1927) Sur les modifications directes et sur la régulation réflexe de l'activité du centre respiratoire de la tête isolée du chien. Arch Intl Pharmacodyn Thér 33: 273-372

HEYMANS C, RIJLANT P (1933) Le courant d'action du nerf du sinus carotidien intact. Compt Rend Soc Biol 113: 69-73

HEYMANS C, BOUCKAERT JJ, DAUTREBANDE L (1930) Sinus carotidien et réflexes respiratoires. II. Influences respiratoires réflexes de l'acidôse, de l'alkalôse, de l'anhydride carbonique, de l'ion hydrogène et de l'anoxémie. Sinus carotidien et échanges respiratoires dans le poumons et au delà des poumons. Arch Intl Pharmacodyn Thér 39: 400-408

HIRSHMAN CA, McCULLOUGH RE, COHEN JP, WEIL JV (1975) Hypoxic ventilatory drive in dogs during thiopental, ketamine or pentobarbital anesthesia. Anesthesiology 43: 628-634

HIRSHMAN CA, McCULLOUGH RE, COHEN JP, WEIL JV (1977) Depression of hypoxic ventilatory response by halothane, enflurane and isoflurane in dogs. Br J Anaesth 49: 957-963
ITURRIAGA R, ALCAYAGA J, ZAPATA P (1988) Contribution of carotid body chemoreceptors and carotid sinus baroreceptors to the ventilatory and circulatory reflexes produced by common carotid occlusion. Acta Physiol Pharmacol Latinoam 38: 27-48

ITURRIAGA R, RUMSEY WL, MOKASHI A, SPERGEL D, WILSON DF, LAHIRI S (1991) In vitro perfusedsuperfused cat carotid body for physiological and pharmacological studies. J Appl Physiol 70: 1393-1400

ITURRIAGA R, LARRAÍN C, ZAPATA P (1994a) Phrenic nerve activity during artificial ventilation at different body temperatures and its relationships with carotid chemosensory activity. Biol Res 27: 145-157

ITURRIAGA R, LARRAÍN C, ZAPATA P (1994b) Effects of dopaminergic blockade upon carotid chemosensory activity and its hypoxia-induced excitation. Brain Res 663: $145-154$

ITURRIAGA R, ALCAYAGA J, ZAPATA P (1996) Dissociation of hypoxia-induced chemosensory responses and catecholamine efflux in cat carotid body superfused in vitro. J Physiol, Lond 497: 551-564

ITURRIAGA R, CERPA V, ZAPATA P, ALCAYAGA J (2003) Catecholamine release from isolated sensory neurons of cat petrosal ganglia in tissue culture. Brain Res 984: 104-110

ITURRIAGA R， REY S， DEL RÍO R (2005) Cardiovascular and ventilatory acclimatization induced by chronic intermittent hypoxia: A role for the carotid body in the pathophysiology of sleep apnea. Biol Res 38: $335-340$

JIANG RG, EYZAGUIRRE C (2004) Effects of hypoxia and putative transmitters on $\left(\mathrm{Ca}^{2+}\right)_{\mathrm{i}}$ of rat glomus cells Brain Res 995: 285-296

JOELS N, NEIL E (1968) The idea of a sensory transmitter. In: TORRANCE RW (ed) Arterial Chemoreceptors. Oxford: Blackwell. pp: 153-178

KATZ DM, ADLER JE, BLACK IB (1987) Catecholaminergic primary sensory neurons: Autonomic targets and mechanisms of transmitter regulation. Fed Proc 46: 24-29

KONDO H (1978) Fine structure of the rat carotid body transplanted into the anterior chamber of the eye. J Neurocytol 7: 505-516

LEITNER LM, LIAUBET MJ (1971) Carotid body oxygen consumption of the cat in vitro. Pflügers Arch 323 315-322

LLADOS F, ZAPATA P (1978a) Effects of dopamine analogues and antagonists on carotid body chemosensors in situ. J Physiol, London 274: 487-499

LLADOS F, ZAPATA P (1978b) Effects of adrenoceptor stimulating and blocking agents on carotid body chemosensory inhibition. J Physiol, London 274: 501-509

LÓPEZ-BARNEO J, LÓPEZ-LÓPEZ JR, UREÑA J, GONZÁLEZ C (1988) Chemotransduction in the carotid body: $\mathrm{K}^{+}$current modulated by $\mathrm{PO}_{2}$ in type $\mathrm{I}$ chemoreceptor cells. Science 241: 580-582

LÓPEZ-BARNEO J, PARDAL R (2003) Carotid body thin slices: New answers for old questions. Lung Biol Health Dis 175: $315-330$

LÓPEZ-LÓPEZ JR, GONZÁLEZ C, PÉREZ-GARCÍA MT (1997) Properties of ionic currents from isolated adult rat carotid body chemoreceptor cells: Effects of hypoxia. J Physiol, Lond 499: 429-441

LOYOLA H, FADIC R, CÁRDENAS H, LARRAÍN C, ZAPATA P (1991) Effects of body temperature on chemosensory activity of the cat carotid body in situ. Neurosci Lett 132: 251-254

MCQUEEN DS (1977) A quantitative study of the effects of cholinergic drugs on carotid chemoreceptors in the cat. J Physiol, Lond 273: 515-532 
MCQUEEN DS (1983) Pharmacological aspects of putative transmitters in the carotid body: In: ACKER $\mathrm{H}$, OREGAN RG (eds) Physiology of the Peripheral Arterial Chemoreceptors. Amsterdam: Elsevier. pp: 149-195

MCQUEEN DS, EYZAGUIRRE C (1974) Effects of temperature on carotid chemoreceptor and baroreceptor activity, J Neurophysiol 37: 1287-1296

NURSE CA, FEARON IM (2002) Carotid body chemoreceptors in dissociated cell culture. Microsc Res Techn 59: 249-255

OBESO A, ALMARAZ L, GONZÁLEZ C (1985) Correlation between adenosine triphosphate levels, dopamine release and electrical activity in the carotid nerve: Support for the metabolic hypothesis of chemoreception. Brain Res 348: 64-68

O'REGAN RG (1979) Responses of the chemoreceptors of the cat carotid body perfused with cell-free solutions. Irish J Med Sci 148: 78-85

PAIVARINTA H, ERÄNKÖ O (1984) Fluorescence microscopical study on fibre formation from carotid bodies from normal or dexamethasone-treated postnatal rats in intraocular transplants to adult rats. Med Biol 62: $181-188$

PARDAL R, LÓPEZ-BARNEO J (2002) Carotid body thin slices: Responses of glomus cells to hypoxia and $\mathrm{K}^{+}$channel blockers. Respir Physiol Neurobiol 132: 69-79

PARDAL R, LUDEWIG U, GARCÍA-HIRSCHFELD J, LÓPEZ-BARNEO J (2000) Secretory responses of intact glomus cells in thin slices of rat carotid body to hypoxia and tetraethylammonium. Proc Natl Acad Sci USA 97: 2361-2366

PEERS C (1990) Hypoxic suppression of $\mathrm{K}^{+}$currents in type I carotid body cells: Selective effect on the $\mathrm{Ca}^{2+}$-activated $\mathrm{K}^{+}$current. Neurosci Lett 119: 253-256

PICK J (1959) The discovery of the carotid body. J Hist Med 14: 61-72

PIETRUSCHKA F (1974) Cytochemical demonstration of catecholamines in cells of the carotid body in primary tissue culture. Cell Tissue Res 151: 317-321

REYES EP, FERNÁNDEZ R, LARRAÍN C, ZAPATA P (2005) Effect of combined cholinergic-purinergic block on carotid body chemosensory activity in situ. J Physiol, Lond 565P: PC169

RIGUAL R, GONZÁLEZ E, FIDONE S, GONZÁLEZ C (1984) Effects of low $\mathrm{pH}$ on synthesis and release of catecholamines in the cat carotid body in vitro. Brain Res 309: 178-181

SAMAAN A, STELLA G (1935) The response of the chemical receptors of the carotid sinus to the tension of $\mathrm{CO}_{2}$ in the arterial blood of the cat. J Physiol, Lond 85: 309-319

SCHMIDT CF (1938) The chemical control of respiration. Chapter XLV in: BARD P (ed) MacLeod's Physiology in Modern Medicine, $8^{\text {th }}$ ed. St Louis: Mosby. pp: 519539

SERANI A, LAVADOS M, ZAPATA P (1983) Cardiovascular responses to hypoxia in the spontaneously breathing cat: Reflexes originating from carotid and aortic bodies. Arch Biol Med Exp 16: 2941

SERANI A, PAZ R, CASTILlO A (2005) The 'wholeanimal approach' as a heuristic principle in neuroscience research. Biol Res 38: 359-364

SHIRAHATA M, ISHIZAWA Y, IGARASHI A, FITZGERALD RS (1996) Release of acetylcholine from cultured cat and pig glomus cells. Adv Exp Med Biol 410: 233-237

SHIRAHATA M, FITZGERALD RS, SHAM JS (1997) Acetylcholine increases intracellular calcium of arterial chemoreceptor cells of adult cats. J Neurophysiol 78: 2388-2395

STEA A, NURSE CA (1992) Whole-cell currents in two subpopulations of cultured rat petrosal neurons with different tetrodotoxin sensitivities. Neuroscience 47: 727-736

STEA A, ALEXANDER SA, NURSE CA (1991) Effects of $\mathrm{pH}_{\mathrm{i}}$ and $\mathrm{pH}_{\mathrm{e}}$ on membrane currents recorded with the perforated-patch method from cultured chemoreceptors of the rat carotid body. Brain Res 567: 83-90

TORRANCE RW (ed) (1968) Arterial Chemoreceptors. Oxford: Blackwell. pp: 402

VALDÉS V, VARAS R, ITURRIAGA R, ALCAYAGA J (2004) Characterization of nicotine receptors in cultured cat petrosal ganglion neurons. Biol Res 37: R54

VARAS R, ALCAYAGA J, ZAPATA P (2000) Acetylcholine sensitivity in sensory neurons dissociated from the cat petrosal ganglion. Brain Res 662: 201-205

VERNA A, ROUMY M, LEITNER L-M (1981) Ultrastructural features of the carotid body after in vitro experiments: Correlation with physiological results. J Neurocytol 10: 659-670

VIDRUK EH, DEMPSEY JA (1980) Carotid body chemoreceptor activity as recorded from the petrosal ganglion in cats. Brain Res 181: 455-459

VON EULER US, LILJESTRAND G, ZOTTERMAN Y (1939) The excitation mechanism of the chemoreceptors of the carotid body. Skand Arch Physiol 83: 132-152

VON EULER US, LILJESTRAND G, ZOTTERMAN Y (1941) Über den Reizmechanismus der Chemorezeptoren im Glomus Caroticum. Acta Physiol Scand 1: 383-385

ZAPATA P (1975) Effects of dopamine on carotid chemoand baroreceptors in vitro. J Physiol, London 244: 235251

ZAPATA P (1977) Modulatory role of dopamine on arterial chemoreceptors. Adv Biochem Psychopharmacol 16: 291-298

ZAPATA P (1997a) Chemosensory activity in the carotid nerve: Effects of physiological variables. In: GONZÁleZ C (ed) The Carotid Body Chemoreceptors. Berlin: Springer-Verlag. pp: 97-117

ZAPATA P (1997b) Chemosensory activity in the carotid nerve: Effects of pharmacological agents. In: GONZÁlEZ C (ed) The Carotid Body Chemoreceptors. Berlin: Springer-Verlag. pp: 119-146

ZAPATA P (2003) From oxygen sensing to chemosensory activity: The mediator role of glomus cells. Lung Biol Health Dis 175: 353-363

ZAPATA P, LARRAÍN C (1978) Antagonism of dopamine-induced chemosensory inhibition by ergot alkaloids. Neurosci Lett 8: 131-136

ZAPATA P, TORREALBA F (1984) Blockade of dopamine-induced chemosensory inhibition by domperidone. Neurosci Lett 51: 359-364

ZAPATA P, ZUAZO A (1980) Respiratory effects of dopamine-induced inhibition of chemosensory inflow. Respir Physiol 40: 79-92

ZAPATA P, ZUAZO A (1982) Reversal of respiratory responses to dopamine after dopamine antagonists. Respir Physiol 47: 239-255

ZAPATA P, HESS A, BLISS EL, EYZAGUIRRE C (1969a) Chemical, electron microscopic and physiological observations on the role of catecholamines in the carotid body. Brain Res 14: 473-496

ZAPATA P, HESS A, EYZAGUIRRE C (1969b) Reinnervation of carotid body and sinus with superior laryngeal nerve fibers. J Neurophysiol 32: 215-228 
ZAPATA P, ZUAZO A, LLADOS F (1976a) Acute changes in ventilation and blood pressure induced by inhalation of tobacco smoke. Arch Intl Pharmacodyn Thér 219: 116-127

ZAPATA P, ZUAZO A, LLADOS F (1976b) Respiratory and circulatory reflexes induced by nicotine injections: Role of carotid body chemoreceptors. Arch Intl Pharmacodyn Thér 219: 128-139

ZHONG H, NURSE C (1996) Co-cultures of rat petrosal neurons and carotid body type I cells. A model for studying chemosensory mechanisms. Adv Exp Med Biol 410: 189-193

ZHONG H, NURSE C (1997) Nicotinic acetylcholine sensitivity of rat petrosal sensory neurons in dissociated cell culture. Brain Res 766: 153-161

ZHONG H, ZHANG M, NURSE C (1997) Synapse formation and hypoxic signaling in co-cultures of rat petrosal neurones and carotid body type 1 cells. J Physiol, Lond 503: 599-612

ZOTTERMAN Y (1935) Action potentials in the glossopharyngeal nerve and in the chorda tympani. Skand Arch Physiol 72: 73-77

ZUAZO A, ZAPATA P (1980) Regulatory role of carotid nerve afferences upon the frequency and pattern of spontaneous gasp complexes. Neurosci Lett 16: 111116 